\title{
Max Theiler (1899-1972): Creator of the yellow fever vaccine
}

\author{
Siang Yong ${\underline{\text { Tan }^{1}}}^{1}$ MD, JD, Kate $\underline{\text { Pettigrew }}^{2}$
}

Y ellow fever is a tropical disease that was once a major cause of gastrointestinal bleeding, liver failure and death for both civilians and soldiers in the Americas. Credit for conquering the disease goes to Cuban epidemiologist Carlos Finlay and United States (US) army surgeon Walter Reed, who demonstrated that the Aedes aegypti mosquito was the vector and described the disease's natural history. Although their discovery led to aggressive mosquito control that was greatly effective, it remained for Dr Max Theiler to develop a vaccine against the dreaded disease. Dr Theiler made his discovery at the Rockefeller Institute after he moved to the US, and capped his career by winning the 1951 Nobel Prize in Medicine.

Dr Theiler was born on 30 January 1899 in Pretoria, South Africa. The son of a well-known Swiss veterinary scientist, he was the youngest of four motivated and successful children. Building on a strong educational foundation by way of private schooling in South Africa and Switzerland, he attended the University of Cape Town Medical School for premedical studies. He then went to London, England, to complete his training at Saint Thomas' Hospital, where he was introduced to the exciting field of infectious diseases. At age 23, he received his medical degree and then set off for the US as a first assistant in the Department of Tropical Medicine at Harvard Medical School, Boston, MA.

\section{OF MICE, MEN AND VACCINES}

While Dr Theiler's early work at Harvard focused on amoebic dysentery and rat bite fever, he soon developed an enduring interest in yellow fever. In 1927, he and his colleagues began to tackle the controversy regarding its aetiology, complementing ongoing studies at the Rockefeller Foundation in New York, US, the premier centre of yellow fever research at that time. He provided proof that the cause of the disease was not a bacterium but a virus, confirming the findings of Dr James Carroll, a colleague of Dr Walter Reed's, that a filterable agent present in blood - compatible with a virus - was the causative agent. In 1930, Dr Theiler relocated to the International Health Division of the Rockefeller Foundation, where he stayed for about 30 years, thriving in this paradise of scientific experimentation and cutting-edge research.

One of Dr Theiler's main contributions was his demonstration that the yellow fever virus could be easily transmitted to mice. Before this finding, monkeys served as the primary experimental animal. The availability of mice made this a simple solution to greatly reduce costs, improve efficiency and, ultimately, produce a vaccine. He developed a convenient test for detecting protective yellow fever antibodies, which would enable the development of human yellow fever vaccines. Dr Theiler and his colleagues also found that passing the disease from mouse to mouse weakened the virus; this finding subsequently formed the basis for two separate vaccines. The first was a weakened strain used in the 1930s and 1940s by the French government to protect the residents of French territories in Western Africa. The second and improved version, known as 17D, was grown in chicken embryos and was more effective and easier to mass-produce. The launch of this new vaccine took place in Brazil in 1938, and it proved to be highly successful. Within a few years, the Rockefeller Foundation provided millions of doses of the vaccine to people in endemic countries. Over the 60 years that followed, more than 400 million doses of the $17 \mathrm{D}$ virus vaccine were administered. This safe and effective vaccine is still produced today by essentially the same methods that Dr Theiler and his colleagues had used.

A NOBEL PRIZE Dr Theiler was first nominated for the Nobel Prize in Physiology or Medicine in 1937, but was not awarded the Nobel Prize until 14 years later. After over a decade in which Dr Theiler was a 'close runner-up', all but two of the Nobel Prize committee members finally agreed to award him the prize in 1951. The two disagreeing members felt that it should have been given to Dr Selman A Waksman for his discovery of streptomycin, the first antibiotic effective against tuberculosis. Dr Theiler received his Nobel Prize based on only three nominations, in contrast to the 39 nominations Dr Waksman had accumulated over six years. Dr Albert Sabin, the father of the live polio vaccine and an influential voice, is believed to have played a dispositive role for Dr Theiler with his nominating letter written in 1948.

In Dr Theiler's speech at the Nobel Banquet in Stockholm, Sweden, on 10 December 1951, he described the evolution of yellow fever research and announced that the conquest of this disease had been one of the great epics in medical history. With graciousness and humility, Dr Theiler focused much of his speech on the work of others rather than himself. He explained: "I like to feel that in honouring me, you are honouring all the

${ }^{1}$ Emeritus Professor of Medicine, University of Hawaii, ${ }^{2}$ Research carried out during medical student clerkship at the John A Burns School of Medicine, University of Hawaii, Honoulu, USA

Correspondence: Prof Tan Siang Yong, 2226 Liliha Street, Suite B-104, Honolulu, HI 96817, USA. siang@hawaii.edu 
workers in the laboratory, field and jungle who have contributed so much, often under conditions of hardship and danger, to our understanding of this disease. I would also like to feel that you are honouring the memory of those who gave their lives in gaining knowledge which was of inestimable value. They were truly martyrs of science, who died that others might live." Dr Theiler was referring to experiments conducted by the army commission led by Dr Walter Reed in Cuba. There, many workers perished, and 22 human volunteers who consented to be bitten by the vector mosquito came down with the disease, including a fatality, Dr Jesse Lazear, a physician member of the commission.

\section{DISCOVERIES BEYOND YELLOW FEVER}

In the year of Dr Theiler's Nobel Prize win, he became the Director of Laboratories of the Rockefeller Foundation's Division of Medicine and Public Health. His work and contributions extended to many other infectious diseases such as Weil's disease, dengue fever and Japanese encephalitis. The problem of poliomyelitis had been one of his special interests, and he succeeded in discovering the aetiologic agent in an almost identical disorder in laboratory mice. The virus, known as Theiler's murine encephalomyelitis virus, is the cause of mice encephalomyelitis, sometimes referred to as Theiler's disease.

Dr Theiler contributed to many journal articles, which were mostly published in The American Journal of Tropical Medicine and Annals of Tropical Medicine and Parasitology. He also wrote chapters in two books, Viral and Rickettsial Infections of Man (1948) and Yellow Fever (1951). In addition to the Nobel Prize, Dr Theiler received many other awards throughout his career, including the Chalmers Medal of the Royal Society of Tropical Medicine and Hygiene (1939), the Flattery Medal (1945) and the Lasker Award (1949).
THE MAN BEHIND THE SCIENTIST A humble man at heart, Dr Theiler remained self-aware about his worth and hard work amid the accolades. He was considered a man of paradoxes, as he often contradicted himself when discussing his achievements and his conditions for 'good science'. For example, he would argue that he had not done anything fundamental and that he did not have any background for making essential theoretical contributions. Yet, he also made it clear that it was he alone who took the essential initiatives in the experiments that led to the development of the vaccine.

While much has been written on Dr Theiler's accomplishments and work in the laboratory, little is known about his personal life. He married Lillian Graham in 1928 and they had one daughter. Although he immigrated to the US in 1923 and remained there for the rest of his life, he never applied for citizenship. When asked what he would do with the money - approximately USD 32,000 that came with his Nobel Prize, Theiler replied that he would buy a case of Scotch and watch the Brooklyn Dodgers play baseball.

After he retired from the Rockefeller Foundation in 1964, Dr Theiler became professor of epidemiology and microbiology at Yale University, where he remained until 1967. He died of lung cancer on 11 August 1972, at the age of 73.

\section{BIBLIOGRAPHY}

- Nobelprize.org. Max Theiler - Banquet Speech [online]. Available at: http://www.nobelprize.org/nobel_prizes/medicine/laureates/1951/theilerspeech.html. Accessed January 20, 2017.

- Norrby E. Yellow fever and Max Theiler: the only Nobel Prize for a virus vaccine. J Exp Med 2007; 204:2779-84.

- Tan SY, Ahana A. Walter Reed (1851-1902): On the cause of yellow fever. Singapore Med J 2010; 51:360-1.

- Shampo MA, Kyle RA. Max Theiler--Nobel Laureate for yellow fever vaccine. Mayo Clin Proc 2003; 78:728.

- Soylent Communications. Max Theiler. In: NNDB: tracking the entire world [online]. Available at http://www.nndb.com/people/561/000129174/. Accessed January 20, 2017. 